\title{
Differences in Increasing Mathematical Critical Thinking Ability of Students Using the STAD and Jigsaw Cooperative Learning Model for Junior High School Students
}

\author{
Desy Ayu Novianti ${ }^{1, *}$ Mulyono² Bornok Sinaga ${ }^{3}$ \\ ${ }^{1,2,3}$ State University of Medan \\ "Corresponding author.Email: desyayunovianti@gmail.com
}

\begin{abstract}
This study aims to analyze the differences in increasing mathematical critical thinking skills between students who are taught using the STAD Type Cooperative learning model and students who are taught using the Jigsaw Cooperative learning model, as well as to describe the process of solving students' answers in solving problems on mathematical critical thinking skills using the model. STAD and Jigsaw Type Cooperative learning. This research is a quasiexperimental research conducted at Al-Hikmah Private Junior High School Medan with a research sample of 64 students with 32 students in each class, VII-7 class as Experiment I class and VII-6 class as Experiment II class. The data were obtained through the KAM test and students' mathematical critical thinking skills tests. Data were analyzed by two-way ANACOVA test. Before using the two-way ANACOVA test, normality and homogeneity tests were first carried out with a significant level of 5\%. Based on the results of the analysis (ANACOVA), there are differences in the improvement of mathematical critical thinking skills between students who are taught using the STAD Type Cooperative learning model and students who are taught using the Jigsaw Cooperative learning model. The magnitude of the significant value obtained from ANACOVA, namely thit $>\mathrm{ttab}=4,360>1,672$ and $\mathrm{p}$-value $/ 2<\alpha=0<0,05$, this means that $\mathrm{H}_{0}$ is rejected. Thus, students' mathematical critical thinking skills taught using the STAD Type Cooperative learning model were higher than students taught using the Jigsaw Cooperative learning model after controlling for the pretest. Then based on the description of the process of completing students' answers in solving mathematical critical thinking ability test questions, it was found that the student's answer process in the STAD Type Cooperative learning model was better than the Jigsaw Cooperative learning model.
\end{abstract}

Keywords: STAD and Jigsaw Type Cooperative, Mathematical critical thinking ability, Early Mathematical Ability (KAM).

\section{INTRODUCTION}

Mathematics is a branch of basic science that plays an important role in the development of Science and Technology (IPTEK). Sary, et al (2019) stated that mathematics is a branch of science that has an important role in the intellectual life of the nation, both in the development of science and technology, as well as as a tool in the application of other fields of science and in the development of mathematics itself. Supported by Skemp (1971) states that mathematics is an important requirement and in general to achieve the desired goal. It is widely recognized as an important tool for knowledge, technology, commerce, and also includes many professions. In a world that is constantly changing, someone who understands and can do mathematics will have many opportunities and choices in determining his future. Therefore, to master and develop science and information technology and be able to survive in the everchanging and competitive conditions in the future, it is necessary to have a strong mastery of mathematics from an early age (National Council of Teachers of Mathematics (NCTM), 2000). 
Based on the objectives of learning mathematics in Indonesia stated by BNSP (2006) which states that mathematics subjects are given to all students from elementary to secondary schools to provide students with the ability to think logically, analytically, systematically, critically and creatively, and the ability to cooperate. One aspect of this research is the ability to think critically. The importance of critical thinking skills in learning mathematics is stated by Chukwuyenum (2013), Critical Thinking has been one of the tools used in our daily life's to solve some problems because it involves logical reasoning, interpreting, analyzing and evaluating information to enable one take reliable and valid decisions.

The above statement is reinforced by Kurniati \& Astuti (2016) which states that students' critical thinking skills will be very useful for their future because students who have critical thinking skills can decide and solve the problems they will face. Thus, mathematical critical thinking skills can help students determine the truth of the information presented and help students realize illogical thinking.

Based on the description above, it is necessary to make efforts to develop critical thinking skills in students in learning mathematics. However, the importance of mathematical critical thinking skills in learning mathematics is not in line with the facts found in the field. This can be seen from an International study in 2011 in the field of mathematics and science Trends in International Mathematics and Science Study (TIMSS) for Junior High Schools (SMP), showing evidence that non- routine math problems that require critical thinking (level thinking skills) high) was not answered correctly by the sample of students who took part in the study, and Indonesia's achievement was still below the average, while the percentage achievement for the cognitive domain was $35 \%$ for knowing, $40 \%$ for applying, and $25 \%$ for reasoning (Noordyana, 2016).

Relatively worse performance in the Program for International Student Assessment (PISA) published by the Organization for Economic Cooperation and Development (OECD) states that Indonesia is only slightly better than Peru, which is ranked at the bottom. The average math score of Indonesian children is 375 , the average reading score is 396 , and the average score for science is 382. In fact, the average OECD scores are 494, 496, and 501 respectively (Khoirotunnisa, 2017).

Then based on the initial observations made by the researcher on the seventh grade students of Al-Hikmah Private Junior High School Medan, several tests were given in the form of descriptions, some of which were obtained from the 2013 curriculum student books and a collection of National Examination (UN) questions to see how the students' initial mathematical abilities (KAM) were. Of the 39 students who were given the test, there were 12 students who were able to answer the questions with the correct final result. Based on the results obtained, the initial mathematical ability (KAM) of students in the field is still relatively low. This can be seen from the process of student answers in solving problems that are still not as expected. Students have not been able to solve problems on algebraic material that should have been studied previously.

Then based on the results of interviews conducted by researchers with teachers, it is known that what often happens when students solve math problems, students are not accustomed to identifying questions, namely writing down what is known and asked in the questions. Most of the students, that is, directly write down the mathematical model and use the answer completion strategy. This is not in accordance with the statement put forward by Ismaimuza (2011) that the first indicator of mathematical critical thinking ability is to identify. Broadly speaking, judging from the student's answer process in this initial observation, it has not met the indicators of critical thinking ability, so it can be said that students' critical thinking ability is still low.

In an effort to improve students' mathematical critical thinking skills, a teacher should pay attention to students' cognitive development. Piaget (Noordyana, 2016) states that human cognitive development is a psychological process in which it involves processes of acquiring, compiling and using knowledge, as well as mental activities, such as: remembering, thinking, weighing, observing, analyzing, synthesizing, evaluating, and solve problems that take place through interaction with the environment.

Based on the description above, the teacher's role in learning as a facilitator and motivator is needed by students to improve students' critical and mathematical thinking skills in the classroom, one of which is by applying a learning model that involves more students actively in the learning process. According to Rosyida (2016), one way to improve the quality of learning is by increasing the relevance of the teaching model. The teaching model is said to be relevant if in the process it is able to deliver students to achieve educational goals. Therefore, efforts are needed to be able to convey subject matter to students with models that are relevant to student needs.

However, in reality there are still many teachers who teach monotonously, using a learning model that is only teacher-centered, thus making students passive in class. Supported by research by Chukwuyenum (2013), which states that, the traditional way of teaching Mathematics in some Nigerian public secondary schools is a teachercentre approach. This method sometimes involves repetition and memory of previously taught material by filling the students' minds with knowledge of Mathematics without explaining in detail the process of analyzing, evaluating and arriving at a conclusion. In addition, these processes may not make the students to be 
critical in thinking because some of them might find it difficult to apply the knowledge acquired to solve mathematical problems in a new situation.

The above statement is supported by Pambudi (2007), who argues that the old paradigm shows that teachers still use conventional learning models, which rely on "chalk and talk" and textbooks that are ready to be fed to their students. In general, students are only asked to come, sit, listen, and memorize in class. Such teaching results in students only learning procedurally and understanding mathematics without going through reasoning.

To overcome the problems above, an alternative that can be used is to apply the cooperative learning model. Cooperative learning model is a learning model that involves students interacting and collaborating with friends, thus making students more active in the classroom. In this case the cooperative learning model that can be applied is the Student Team Achievement Division (STAD) and Jigsaw cooperative learning model.

\section{LITERATURE REVIEW}

\subsection{Mathematical Critical Thinking Ability}

In everyday life, humans cannot be separated from thinking activities, because thinking is a characteristic that distinguishes humans from other living things. Hasratuddin (2018) states that thinking occurs in every human mental activity and functions to formulate or solve problems, make decisions, and seek understanding.

Technically, thinking ability in Bloom's taxonomy is defined as intellectual ability, namely the ability to analyze, synthesize, and evaluate. The students' thinking level can be divided into two, namely basic level thinking and higher order thinking. Resnick (Fatmawati, et al, 2014) states that lower order thinking only uses limited abilities in routine and mechanical things. Meanwhile, higher order thinking allows students to interpret, analyze or even be able to manipulate previous information so that it is not monotonous. The above statement is emphasized by Johnson (2014), that thinking skills are grouped into basic thinking skills and higher- order thinking skills, and those included in higher- order thinking skills are critical thinking skills. Many experts have defined critical thinking.

Robert Ennis is one of the well-known contributors to the development of critical thinking which has been widely circulated in the field of education. Ennis (1996) states that critical thinking is reflective thinking focused on deciding what to believe and do. According to Edward Glaser, one of the authors of the Watson-Glaser Critical Thinking Appraisal (the most widely used critical thinking ability test worldwide), defines critical thinking as:
(1) An attitude of wanting to think deeply about problems and matters differ in the range of one's experience; (2) knowledge of examination strategies and logical reasoning; (3) a kind of skill to implement those strategies. Critical thinking demands a great effort to examine every belief or assumptive knowledge based on the supporting evidence and the further conclusions that result from it (Kurniati \& Astuti, 2016).

According to Paul (Kowiyah, 2012) provides a definition that Critical thinking is that mode of thinkingabout any subject, content or problem-in which the thinker improves the quality of his or her thinking by skillfully taking change of the structures inherent in thinking and imposing intellectual standards upon them.

In his book, Hasratuddin (2018) states that critical thinking as part of thinking skills is an ability to make decisions rationally or with reason. Then Fisher (1995) argues that critical thinking is explaining what is thought.

Considering the definition of critical thinking from the experts above, it can be concluded that critical thinking ability is one of the higher- order thinking skills that a person does in an activity or cognitive process to gain knowledge, understanding and skills in order to be able to find a way out or a solution as well as conclusions from a problem. problem.

Someone who is able to think critically not only to solve problems, but also to give reasonable reasons for the solutions he gives, because basically thinking is an activity carried out to reach a conclusion. The process of making decisions or drawing conclusions must be done carefully and not in a hurry. This means that critical thinking requires the use of various strategies to be able to produce decisions as a basis for taking actions or beliefs.

Meanwhile, the ability to think critically mathematically is one of the skills and abilities that must be developed in learning mathematics and is one of the competency standards for graduates from primary to secondary education. Therefore, a teacher must be able to seek a learning that can overcome difficulties and improve students' mathematical critical thinking skills.

The TBK criteria adapted to the critical thinking indicators according to Ennis (1993), are able to: (1) formulate the main points of the problem; (2) reveal the existing facts; (3) choose a logical argument; (4) detecting bias with different viewpoints; (5) draw conclusions; so that the following criteria are produced: (1) TBK 0 , ie there is no answer that matches the critical thinking indicator according to Ennis; (2) TBK 1, namely students' answers according to two or three critical thinking indicators according to Ennis; (3) TBK 2, namely students' answers according to the four critical thinking indicators according to Ennis; (4) TBK 3, namely students' answers according to the five critical thinking indicators according to Ennis. 
Then Minarni \& Napitupulu (2019) states that, High order thinking skills (HOTS) are higher order thinking skills such as analyzing, evaluating, and synthesizing. HOTS involves the ability to conclude a complex problem, think critically and creatively, solve a problem, and metacognitive skills. HOTS are more difficult to learn or teach, but are more valuable because they help and enable one to deal with new problems that need solving.

In this study, researchers used critical thinking skills indicators modified by Ikman et al (2016) from Ismaimuza, namely: the ability to identify mathematical concepts, analyze, connect between concepts, solve problems, and evaluate. The five aspects are described as follows:

1. Identifying the concept is a skill to describe the structure into components that determine the organizational structure. Aspects of identifying concepts include: writing down what is known and asked about this problem.

2. Analyzing is to describe and understand various aspects gradually to arrive at a new formula. Aspects analyzed include: being able to define concepts/definitions/theorems in solving problems clearly and precisely.

3. Connecting between concepts is combining parts into a new formation or arrangement. Aspects related to the concept include: being able to apply concepts/definitions/theorems in solving problems.

4. Solve mathematical concept problems into an application problem solving. Aspects of problem solving include: procedures and results indicate the main problem solving / determination of solutions / answers.

5. Evaluating is giving an assessment of the value measured by using certain standards. Evaluation aspects include: re-examining solutions/answers and determining conclusions from a problem.

The indicators of mathematical critical thinking skills listed above can be summarized in Table 2.1.

Table 2.1. Indicator of Mathematical Critical Thinking Ability

\begin{tabular}{|c|l|c|}
\hline No. & $\begin{array}{c}\text { Aspects to } \\
\text { be } \\
\text { measured }\end{array}$ & Indicator \\
\hline 1. & Identify & 1.1 Write down what you know \\
\cline { 3 - 4 } & & $\begin{array}{c}1.2 \text { Can explain what is asked in } \\
\text { the question }\end{array}$ \\
\hline 2. & Analyze & $\begin{array}{r}2.1 \text { Can determine the concept / } \\
\text { definition / theorem in } \\
\text { solving problems clearly }\end{array}$ \\
\hline
\end{tabular}

\begin{tabular}{|c|c|c|}
\hline & & $\begin{array}{l}\text { 2.2 Can determine the concept / } \\
\text { definition / theorem in } \\
\text { solving problems } \\
\text { appropriately }\end{array}$ \\
\hline 3. & Connecting & $\begin{array}{l}\text { 3.1 Able to apply concepts to } \\
\text { solve problems }\end{array}$ \\
\hline \multirow[t]{2}{*}{4.} & \multirow[t]{2}{*}{$\begin{array}{l}\text { Solve } \\
\text { problems }\end{array}$} & $\begin{array}{l}\text { 4.1 Demonstrate procedures in } \\
\text { problem } \\
\text { solving/determination of } \\
\text { solutions/answers }\end{array}$ \\
\hline & & $\begin{array}{l}\text { 4.2 Shows the main results in } \\
\text { problem solving/ solution } \\
\text { determination/ answers }\end{array}$ \\
\hline \multirow[t]{2}{*}{5.} & \multirow[t]{2}{*}{ Evaluation } & $\begin{array}{l}5.1 \text { Re-examine } \\
\text { solutions/answers }\end{array}$ \\
\hline & & $\begin{array}{l}\text { 5.2 Determining the conclusion } \\
\text { from the answer }\end{array}$ \\
\hline
\end{tabular}

(Ikman, et al, 2016)

\subsection{STAD Type Cooperative Learning Model}

Efforts to achieve learning goals in junior high school have implemented various lessons, including cooperative learning, one of which is Student Teams Achievement Divisions (STAD) cooperative learning. STAD was developed by Robert Slavin et al., at Johns Hopkins University.

According to Slavin (2007), the STAD model is the most studied variation of cooperative learning. This statement is supported by Sugianto, et al (2014) which states that STAD is the type of cooperative learning that is most studied by education observers and most responded to by students, compared to other types of cooperative learning, because STAD in terms of the stages of learning implementation, is the simplest type, so that students are not too burdened with the specified rules.

Lestari \& Yudhanegara (2015) state that STAD is a type of cooperative learning model that emphasizes team achievement based on team recognition obtained from the sum of all individual progress scores of each team member. Then Setyawan, et al (2013) stated that STAD type cooperative learning is one way in cooperative learning that can foster cooperative skills, think critically and can help friends in understanding the subject matter together.

More broadly, Tran (2013) suggests that cooperative learning using STAD is effective in improving students' academic achievement and also a positive attitude towards mathematics. This increase in student achievement is due to the active involvement of students in learning. Students are given many opportunities to build their own knowledge. Students explain and receive explanations from among students in a group, where this concept can be easily understood.

In addition, with the mathematics lessons that students have taken at school, they can practice the 
mathematical concepts from the school applied in everyday life. STAD type cooperative learning is learning that prioritizes students in study groups that involve more students than the previous method, and the results of the study state that using STAD type cooperative learning can increase students' mathematical activity and critical thinking.

Based on the definition of STAD learning above, in general it can be concluded that STAD was developed to create a learning system that makes it easier for students to improve their cognitive and affective abilities by learning to understand the subject matter together without meaningless competition between students.

\subsection{Steps of the STAD Type Cooperative Learning Model}

The main characteristic of STAD type cooperative learning is to motivate students in a group to encourage each other, work together and help each other to complete the information or skills being studied for individual quizzes. This cooperative learning also emphasizes the existence of an award so that students are more motivated to learn. The existence of these awards can motivate students to be better in dealing with individual quizzes, namely getting the best score.

In this study, researchers used the steps of the STAD type cooperative learning model from Hosnan (2014), namely:

1. Form a heterogeneous group of 4-5 members (mixed according to achievement, gender, ethnicity, etc.).

2. The teacher presents the subject matter.

3. The teacher gives a task to the group to be done by group members. Group members who know explain to other members until all members in the group understand.

4. The teacher gives quizzes or questions to all students. At the time of answering the quiz should not help each other.

5. Quiz discussion and evaluation.

6. Conclusion.

Cooperative learning conditions students learn from experience and participate actively in solving problems or problems given by the teacher. The existence of student interaction in groups allows students not to hesitate to ask their group friends to be able to understand the subject matter given by the teacher.

The advantages of the STAD type cooperative learning model according to Roestiyah (2001), are: a) Can provide opportunities for students to use the skills of asking and discussing a problem, b) Can provide opportunities for students to more intensively conduct investigations on a problem, c) Can develop leadership talents and teach discussion skills, d) Can enable teachers to pay more attention to students as individuals and their learning needs, e) Students are more actively involved in their lessons and they are more active in discussions, $\mathrm{f}$ ) Can provide opportunities for students to develop a sense of respect, respect for his friends, and respect the opinions of others.

The shortcomings of the STAD type cooperative learning model according to Khusna (2011) the weaknesses of STAD are: a) Learning using this model takes a relatively long time, taking into account the three time-consuming STAD steps such as presenting material from the teacher, group work and individual tests/quizzes, because the average number of students in the class is 45 people, so the teacher is less than optimal in observing group learning in turn, b) Teachers are required to work quickly in completing tasks related to the learning that has been done, including correcting student work, determining changes study groups, require a lot of time and money to prepare and then carry out cooperative learning, c) Require longer time for students so that it is difficult to achieve curriculum targets, requires special abilities of teachers so that not all teachers can do cooperative learning, demands certain characteristics from participants in sis, for example the nature of like to work together.

\subsection{Jigsaw Type Cooperative Learning Model (Expert Team)}

Jigsaw is one type of flexible cooperative learning method. This model was developed and tested by Elliot Aronson and his friends at the University of Texas. The meaning of Jigsaw in English is a jigsaw and there are also those who call it a puzzle, which is a puzzle putting together pieces of a picture. This Jigsaw cooperative learning model takes the pattern of how to work a saw (zigzag), where students do a learning activity by working together with other students to achieve a common goal.

Basically, in this model the teacher divides large units of information into smaller components. Furthermore, the teacher divides the students so that each member is responsible for mastering each component/subtopic assigned by the teacher as well as possible. Students from each group who are responsible for the same subtopic form another group of two or three people. A number of studies have been carried out by researchers related to Jigsaw cooperative learning with different editors, but in the same or almost the same concept.

Syarifah (2017) states that the jigsaw type cooperative learning model is a learning model in which students learn in small groups consisting of 4-5 people by paying attention to heterogeneity, working together positively and each member is responsible for studying certain problems from the material provided and delivering the material. it to other group members. Then Arends (1997) stated that "Jigsaw type cooperative learning is a type of cooperative learning that consists of 
several members in a group who are responsible for mastering the part of the learning material and are able to teach that part to other members in the group". In line with the statement above, Rusman (2010) stated that the Jigsaw learning model is also known as the cooperative of experts. Because each group member is faced with different problems. But the problems faced by each group are the same, each envoy in a different group discusses the same material, we call it a team of experts in charge of discussing the problems faced, then the results of the discussion are brought to the home group and conveyed to the group members.

Slavin (2008), on the use of the Jigsaw type cooperative learning model, it is necessary to prepare the following:

\section{Material}

Before the lesson begins, the teacher selects one or two chapters, stories, or other units then creates an expert sheet for each unit and creates a quiz, essay test, or other form of assessment for each unit. To help guide discussion in expert groups use discussion schemes.

\section{Divide students into initial groups}

Divide students into heterogeneous groups consisting of 4-5 members.

\section{Divide students into expert groups}

Students can be placed in expert groups at random or by deciding for themselves which students will enter which expert group.

\section{4. $\quad$ First scoring}

The initial score represents the student's average score on the previous quiz or if the quiz has never been held, it can use the results of the student's last score from the previous year.

According to Syaripah (2017), the implementation of Jigsaw can increase student active participation and assist teachers in managing the teaching and learning process. Charania et al., (2001) stated that the Jigsaw learning strategy supports the development of critical thinking skills. In line with the above opinion, Manahal (Almukarram, et al, 2016) found that Jigsaw cooperative learning is one of the lessons that leads to critical thinking skills and can motivate students to investigate problem solving in real life situations. and stimulate students to produce a work.

From some of the opinions of the experts above, the researcher can conclude that the Jigsaw cooperative learning model is a type of learning that focuses on group cooperation in small groups consisting of 4 to 6 students by representing one student in each group to become a team of experts.

\subsection{Steps of the Jigsaw Cooperative Learning Model (Team of Experts)}

The Jigsaw learning strategy has a prominent character, namely the intensity of student cooperation in groups is high. There has been a lot of research, especially in the field of mathematics education that uses the Jigsaw type cooperative model and arranges learning steps. In this study, researchers used the steps of learning the Jigsaw type cooperative model from Rosyidah (2016), which are as follows:

\section{Preliminary activities}

1. The teacher conditions the students and conveys the learning objectives to the students.

2. The teacher directs the students to the learning model that will be used.

3. The class is divided into several groups whose members consist of 4-6 students heterogeneously and are referred to as the home group.

\section{Core activities}

1. Each student in each home group is given one part of the material to be discussed.

2. Group members who get the same part of the material gather into one group and are called expert groups whose members consist of 4-6 students.

3. Students in the expert group discuss the part of the material that is their responsibility.

4. Students in the expert group return to their home group to teach other members about the material they have learned in the expert group.

\section{Closing Activities}

1. After discussion in the home group, all students are evaluated individually regarding all the material that has been studied.

2. After the evaluation, scores and group awards are given.

Arends (2008) illustrates Jigsaw cooperative learning in Figure 2.1.

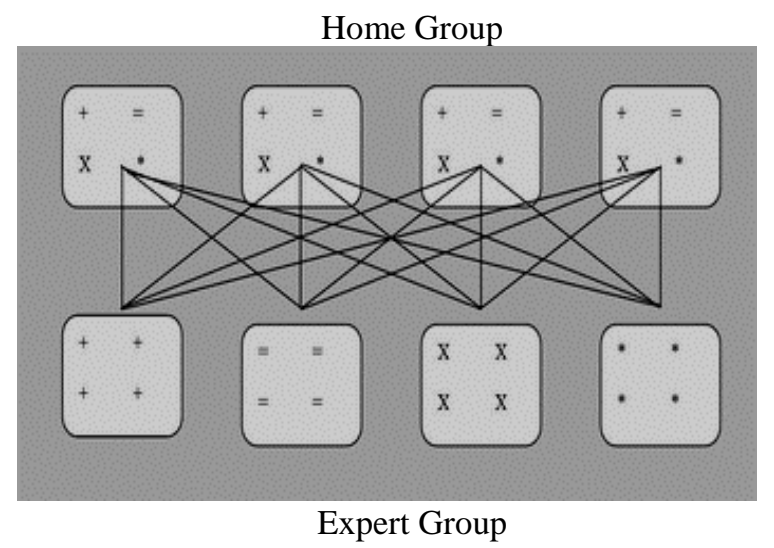

Figure 2.1. Jigsaw Learning Illustration 
Isjoni (2011) states the advantages and disadvantages of Jigsaw cooperative learning, which are as follows:

a. The advantages of Jigsaw cooperative learning include:

1. In cooperative classes students can interact with their peers and also with their teachers as mentors.

2. Peer motivation can be used effectively to improve both student's cognitive and student's effective growth.

3. Growing student responsibility.

4. Encourage students to be active and help each other in mastering the subject matter.

5. To optimize the benefits of group learning.

b. The disadvantages of Jigsaw cooperative learning include:

1. Students freely choose quizzes and are given individual grades.

2. Effectively at each level students have gained academic skills from understanding.

\section{METHOD}

This research is an experimental research with the type of research is quasi-experimental (quasiexperiment). This research was conducted at Al-Hikmah Private Junior High School Medan in grade VII. The population in this study were all seventh grade students at Al-Hikmah Private Junior High School Medan totaling 497 students spread into 11 classes. The sample in this study was taken with a random sampling technique (random sampling). Researchers may not take students randomly to form a new class because it will interfere with the learning process at school, so the researcher takes the smallest sampling unit is a class taken as many as two classes where the determination of the sample is done by drawing lots. In this study, two data analysis techniques were used, namely descriptive statistical analysis and inferential statistical analysis. For inferential statistical analysis, a two-way Covariance Analysis (ANACOVA) design was used. The essence of ANACOVA is the use of a linear regression model to eliminate the influence of the uncontrolled variables which are commonly called companion variables or covariates on the criterion variables. The mathematical model for the two-way ANACOVA quoted from Kutner (Syahputra, 2016), is as follows:

$Y_{\mathrm{ij} k}=\mu+a_{\mathrm{i}}+\beta_{\mathrm{j}}+(a \beta)_{\mathrm{ij}}+\gamma\left(\mathrm{X}_{\mathrm{ij} k}-\overline{\mathrm{X}} ..\right)+\mathrm{c}_{\mathrm{ij} k}$

;

$\mathrm{i}=1,2 ; \mathrm{j}=1,2 ; k=1,2,3 \ldots, n$

$$
\mathrm{i}=1,2 ; \mathrm{j}=1,2 ; k=1,2,3 \ldots, n
$$

Information:

$Y_{\mathrm{ij} k}=$ test score of the k-th student, in the i-thKAM, who gets the $\mathrm{j}$ learning $\mu \quad=$ mean test score without treatment

$\alpha_{\mathrm{I}} \quad=$ the effect of the i-th KAM on the ability

$\beta_{\mathrm{j}} \quad=$ the effect of the jth learning on ability

$(a \beta)_{\mathrm{ij}}=$ the interaction effect of the $\mathrm{i}$-th KAM and $\mathrm{j}$-th learning on ability

$\gamma=$ regression coefficient which states the effect of $\mathrm{X}_{\mathrm{ij}}$ on $\mathrm{Y}_{\mathrm{ij}}$

$\mathrm{X}_{\mathrm{ij} k}=$ the pretest score of the $\mathrm{k}$-th student in thei-th KAM who received the $\mathrm{j}$ lesson

$\bar{X} \quad=$ mean score of student pretest

$\mathrm{c}_{\mathrm{ij} k}=$ error component that occurs in the $\mathrm{k}$-thstudent in the $\mathrm{i}$-th KAM which get the $\mathrm{j}$-th learning (actually this component $\mathrm{c}_{\mathrm{ij} k}$ is other influences that are not monitored in the studied variables, therefore every researcher wants thiscomponent to have the smallest value)

$n \quad=$ number of observations (data) on factor $\mathrm{i}$

\section{RESULT AND DISCUSSION}

The data on the results of students' mathematical critical thinking skills were analyzed using descriptive and inferential statistics. The results of the data analysis are as follows:

\section{Average Score of Students' Mathematical Critical Thinking Ability Test Results}

The average student test scores for the Experiment I class and the Experiment II class are summarized in Table 4.1.

Table 4.1. Recapitulation of Average Mathematical Critical Thinking Ability of Students in Experiment I and Experiment II Classes

\begin{tabular}{|c|c|c|c|}
\hline No & $\begin{array}{c}\text { Proportion of } \\
\text { Score }\end{array}$ & $\begin{array}{c}\text { Experiment } \\
\text { I }\end{array}$ & $\begin{array}{c}\text { Experiment } \\
\text { II }\end{array}$ \\
\hline 1 & Pretest & 32,41 & 35,03 \\
\hline 2 & Posttest & 66,25 & 56,80 \\
\hline
\end{tabular}

In Table 4.1. The above shows that the difference in the proportion of pretest and posttest scores in Experiment I class students is greater than the difference in the proportion of pretest and posttest scores in Experiment II class students. This gives an indication that learning using the STAD Type Cooperative model can improve the achievement of students' mathematical critical thinking skills than the Jigsaw Type Cooperative learning. 


\section{N-Gain Test}

The summary of the results of the N-Gain calculation on mathematical critical thinking skills can be seen in Table 4.2.

Table 4.2. N-Gain Results of Students' Mathematical Critical Thinking Ability in Both Learning Groups

\begin{tabular}{|c|c|c|c|c|c|c|}
\hline \multirow{3}{*}{$\begin{array}{c}\text { Aspe } \\
\text { ct }\end{array}$} & \multicolumn{6}{|c|}{ Learning } \\
\hline & \multicolumn{3}{|c|}{ STAD } & \multicolumn{3}{|c|}{ Jigsaw } \\
\hline & $\begin{array}{l}\text { Pre } \\
\text { test }\end{array}$ & $\begin{array}{c}\text { Post } \\
\text { test }\end{array}$ & $\begin{array}{c}N- \\
\text { Gain }\end{array}$ & $\begin{array}{l}\text { Pre } \\
\text { test }\end{array}$ & $\begin{array}{c}\text { Post } \\
\text { test }\end{array}$ & $\begin{array}{c}N- \\
\text { Gain }\end{array}$ \\
\hline $\begin{array}{c}\text { Aver } \\
\text { age }\end{array}$ & $\begin{array}{c}32,4 \\
063\end{array}$ & $\begin{array}{c}66,2 \\
5\end{array}$ & $\begin{array}{c}0,499 \\
4\end{array}$ & $\begin{array}{c}35,0 \\
3\end{array}$ & $\begin{array}{c}56,8 \\
0\end{array}$ & $\begin{array}{c}0,319 \\
9\end{array}$ \\
\hline
\end{tabular}

Based on the description of Table 4.2. above, that the average $\mathrm{N}$-Gain value of mathematical critical thinking skills in the Experiment I class using the STAD Type Cooperative learning model is 0.4994 , which is in the "Medium" category. Meanwhile, for the Experiment II class using the Jigsaw Type Cooperative learning model, the amount is 0.3199, which is in the "Medium" category.

\section{Hypothesis testing}

$H_{0}: \alpha_{1}=\alpha_{2}=0$ (there is no difference in students' mathematical critical thinking skills taught using the STAD Cooperative learning model and the Jigsaw Cooperative learning model)

$H_{1}$ :not $\mathrm{H}_{0} \quad$ (there are differences in students' mathematical critical thinking abilities who are taught using the STAD Cooperative learning model and the Jigsaw Cooperative learning model)

For the results of ANACOVA using F-test statistics with formulas and criteria that have been determined with the help of SPSS software version 19, it can be seen in Table 4.3.

Table 4.3. Covariance Analysis for Complete Design of Mathematical Critical Thinking Ability

Tests of Between-Subjects Effects Dependent Variable:Posttes

Dependent Variable:Posttes
\begin{tabular}{|l|c|c|c|c|c|c|}
\hline Source & $\begin{array}{c}\text { Type III } \\
\text { Sum of } \\
\text { Squares }\end{array}$ & df & $\begin{array}{c}\text { Mean } \\
\text { Square }\end{array}$ & F & Sig. & $\begin{array}{c}\text { Partial } \\
\text { Eta } \\
\text { Squared }\end{array}$ \\
\hline Corrected & $5824,673^{\mathrm{a}}$ & 6 & 970,779 & 11,397 &, 000 &, 545 \\
Model & 10733,687 & 1 & 10733,687 & 126,014 &, 000 &, 689 \\
Intercept & 799,911 & 1 & 799,911 & 9,391 &, 003 &, 141 \\
Model & 835,649 & 2 & 417,824 & 4,905 &, 011 &, 147 \\
KAM & 91,606 & 2 & 45,803 &, 538 &, 587 &, 019 \\
Model * & 55,364 & 1 & 55,364 &, 650 &, 423 &, 011 \\
KAM & 4855,186 & 57 & 85,179 & & & \\
Pretes & 253113,000 & 64 & & & & \\
Error & 10679,859 & 63 & & & & \\
Total & Corrected & & & & & \\
Total & 10679 &
\end{tabular}

a. R Squared $=, 545$ (Adjusted $\mathrm{R}$ Squared $=, 498$ )

Based on the results of the analysis of covariance above, in the Model row, $\mathrm{F}_{\text {hit }}=9.391$ and based on Table
$\mathrm{F}$ for $\alpha=0.05, \mathrm{db}=1.57, \mathrm{~F}_{(0.05 ; 1.57)}=4.01$, so $\mathrm{F}_{\text {hit }}>\mathrm{F}_{\text {tab }}=$ $9.391>4.01$ and $\mathrm{p}$-value $<\alpha=0.003<0.05$. Thus, it can be concluded that there is an average difference in mathematical critical thinking skills between students who are taught using the STAD Type Cooperative learning model and students who are taught using the Jigsaw Cooperative learning model after controlling for the pretest.

\section{Anacova Advanced Test}

$H_{0}: \beta, \leqslant 0 \quad$ (the mathematical critical thinking ability of students who are taught using the STAD Type Cooperative learning model is lower than students who are taught using the Jigsaw Cooperative learning model)

$H_{1}: \beta,>0 \quad$ (the mathematical critical thinking ability of students who are taught using the STAD Type Cooperative learning model is higher than students who are taught using the Jigsaw Cooperative learning model)

For the results of the ANACOVA further test analysis using t-test statistics with formulas and criteria that have been set with the help of SPSS software version 19, it can be seen in Table 4.4.

Table 4.4. ANACOVA Advanced Test Results Mathematical Critical Thinking Ability

\begin{tabular}{|c|c|c|c|c|c|c|c|}
\hline \multirow{2}{*}{ Parameter } & \multirow{2}{*}{ B } & \multirow{2}{*}{ Std. Error } & \multirow{2}{*}{$\mathrm{t}$} & \multirow{2}{*}{ Sig. } & \multicolumn{2}{|c|}{$\begin{array}{l}95 \% \text { Confidence } \\
\text { Interval }\end{array}$} & \multirow{2}{*}{$\begin{array}{l}\text { Partial Eta } \\
\text { Squared }\end{array}$} \\
\hline & & & & & $\begin{array}{l}\text { Lower } \\
\text { Bound }\end{array}$ & $\begin{array}{l}\text { Upper } \\
\text { Bound }\end{array}$ & \\
\hline Intercept & 40,288 & 3,243 & 12,423 &, 000 & 33,804 & 46,773 & 717 \\
\hline [Model=1] & 10,674 & 2,448 & 4,360 &, 000 & 5,779 & 15,569 & 238 \\
\hline [Model=2] & $0^{3}$ & &. & & & & \\
\hline Pretes &, 472 &, 078 & 6,028 &, 000 &, 315 &, 628 &, 373 \\
\hline
\end{tabular}

a. This parameteris set to zero becauseit is redundant.

Based on the results of the t-test analysis in Table 4.4. above, the value of $t_{\text {hit }}=4.360$ is obtained and based on the $\mathrm{t}$ table for $\alpha=0.05, \mathrm{df}=57$, it is obtained that $\mathrm{t}_{\mathrm{tab}}=$ 1.672 , so $\mathrm{t}_{\text {hit }}>\mathrm{t}_{\mathrm{tab}}=4.360>1.672$ and $\mathrm{p}$-value $/ 2<\alpha=0$ $<0.05$, this means that $\mathrm{H}_{0}$ is rejected. Thus, the mathematical critical thinking ability of students who were taught using the STAD Type Cooperative learning model was higher than the students taught using the Jigsaw Cooperative learning model after controlling for the pretest.

\section{Analysis of the Process of Completing Student Answers on Critical Thinking Ability}

The assessment of the student's answer process in the two learning classes uses the students' own assessment of their efforts and the results of their work based on indicators of critical thinking skills. 


\section{Experiment Class I}

Of the 32 students who worked on the first and second questions in the Experiment I class, there were 18 students who showed the results of completing the correct answers with the techniques they used in solving the questions. For the third question in the Experiment I class, there were 13 students who showed the correct answer with the technique they used in solving the problem. For the fourth question in the Experiment I class, there were 11 students who showed the results of completing the correct answer with the technique they used in solving the problem. The rest, students use only guessing the answer strategy and there are even some students who do not show how they work in the answer sheet.

\section{Experiment Class II}

Of the 32 students who worked on the first and second questions in the Experiment II class, there were 10 students who showed the correct answers with the techniques they used in solving the questions. For the third question in the Experiment II class, there were 13 students who showed the results of completing the correct answer with the technique they used in solving the problem. For the fourth question in the Experiment II class, there were 3 students who showed the results of completing the correct answer with the technique they used in solving the problem. The rest, students use only guessing the answer strategy and there are even some students who do not show how they work in the answer sheet.

Based on the description above, several things can be concluded. First, students are not used to identifying problems. Second, there are some students who are not critical of the aspects of analyzing and connecting concepts in the process of answering questions. Third, the majority of students do not yet have a sensitivity to a pattern in the fourth question. Fourth, in the view of critical thinking according to Ikman, et al, students' mathematical critical thinking skills are still low. However, there are some students who have been able to use the five aspects of critical thinking skills well. This indicates that in general, students' sensitivity to patterns in solving problems, especially in terms of mathematical critical thinking skills, still needs to be improved.

\section{CONCLUSION}

Based on the results of data analysis and research findings during the STAD and Jigsaw Cooperative learning, by emphasizing the students' mathematical critical thinking skills, several conclusions were obtained which were the answers to the questions in the problem formulation. The conclusions are as follows:

a. There are differences in the improvement of mathematical critical thinking skills between students who are taught using the STAD Type
Cooperative learning model and students who are taught using the Jigsaw Cooperative learning model. Based on the results of descriptive data analysis after the learning activities were carried out, it was found that the difference in the proportion of pretest and posttest scores in Experiment I class students was greater than the difference in the proportion of pretest and posttest scores in Experiment II class students. Meanwhile, based on the results of inferential analysis, the value of $t_{\text {hit }}=4.360$ is obtained and based on table $\mathrm{t}$ for $=0.05, \mathrm{df}=57$, it is obtained $\mathrm{t}_{\mathrm{tab}}=1.672$, so $\mathrm{t}_{\text {hit }}>\mathrm{t}_{\mathrm{tab}}=4.360>1.672$ and $\mathrm{p}$ - value $/ 2<=0<$ 0.05 , this means that $\mathrm{H}_{0}$ is rejected. Thus, the mathematical critical thinking ability of students who were taught using the STAD Type Cooperative learning model was higher than the students taught using the Jigsaw Cooperative learning model after controlling for the pretest.

b. The process of completing students' answers in solving mathematical critical thinking ability test questions in the STAD Type Cooperative learning model is better than the student's answer process in Jigsaw Cooperative learning.

\section{REFERENCES}

[1] Almukarram, Ali, \& Apriana. 2016. Application of the Environmental Jigsaw Cooperative Learning Model at SMA Negeri 12 Banda Aceh. Biotic Journal. ISSN: 2337- 9812, Vol. 4, No. 1, Ed. April 2016, p. 8-14.

[2] Arends. 1997. Classroom Instruction and Management. New York: Mc. GrawHill Companies.

[3] BNSP. 2006. Permendiknas RI No.22 of 2006 concerning Content Standards for Primary and Secondary Education Units. Jakarta: BNSP.

[4] Charania, Farida, \& Shanaz. 2001. Playing Jigsaw: A Cooperative Learning Experience Journal of Nursing Education. Vol. 40 (9): 420 - 421.

[5] Chukwuyenum. 2013. Impact of Critical thinking on Performance in Mathematics among Senior Secondary School Students in Lagos State. IOSR Journal of Research \& Methods in Education, 3(5), $18-25$.

[6] Ennis. 1993. Critical Thinking Assessment. Theory into Practice. Vol 32, No. 3, pp. 179- 186.

[7] Fatmawati, Mardiyana \& Trianto. 2014. Analysis of Students' Critical Thinking in Solving Mathematical Problems Based on Polya on the Subject of Quadratic Equations (Research on Class X Students of Smk Muhammadiyah 1 Sragen Academic Year 
2013/2014). Electronic Journal of Mathematics Learning Vol.2, No.9, pp. 899- 910, November 2014. ISSN: 2339-168. http://jurnal.fkip.uns.ac.id

[8] Fisher. 1995. Thinking Children to Think, Cheltenham, (United Kingdom: Stanley Thornes Ltd).

[9] Hasratuddin. 2018. Why Should You Learn Mathematics. Medan: Perdana Publishing.

[10] Hosnan. 2014. Scientific and Contextual Approaches in 21st Century Learning. Bogor: Ghalia Indonesia.

[11] Ikman, Hasnawati, \& Rezky. 2016. Effect Of Problem Based Learning (Pbl) Models Of Critical Thinking Ability Students On The Early Mathematics Ability. International Journal of Education and Research. Vol. 4 No. 7 July 2016, ISSN: $\quad 2411-5681, \quad$ Page: 361-374. http:www.ijern.com

[12] Isjoni. 2011. Cooperative Learning Effectiveness of Group Learning. Bandung: Alphabeta.

[13] Ismaimuza. 2011. Mathematical Critical Thinking Ability Judging From Students' Prior Knowledge. Journal of Mathematics Education, Volume 2 Number 1, January 2011, Pages: 11-20.

[14] Johnson. 2014. CTL (Contextual Teaching \& Learning. Bandung: Kaifa.

[15] Khoirotunnisa. 2017. Experimentation of the Jigsaw Puzzle Map Learning Model on Mathematics Learning Achievement in Set Materials Judging from the Personality Type of Class VII Students in Semester 1 MTsN 1 Bojonegoro Academic Year 2015/2016. Scientific Journal of Mathematics Education, Vol. 5 No. 2, March 2017 pp: 82-88.

[16] Khusna. 2011. Efforts to Improve Student Learning Outcomes by Using the STAD Type Cooperative Learning Model. (Online), (http://rullykhusnamakalah-model- pembelajaran-stad.html), accessed on October 25, 2014.

[17] Kowiyah. 2012. Critical Thinking Ability. Journal of Basic Education Vol. 3, No. 5. PP: 175-179. UHAMKA PGSD Lecturer.

[18] Kurniati \& Astuti. 2016. Application of Open Ended Learning Strategies to Students' Critical Thinking Ability in Mathematics Subject Class V at Madrasah Ibtidaiyah Negeri 1 Palembang. PGMI Scientific Junal, Volume 2, Number 1, Pages:1-18. Email: risna_kur@gmail.com

[19] Lestari and Yudhanegara. 2015. Mathematics Education Research. Bandung: PT. Aditama Refika.
[20] Minarni \& Napitupulu. 2019. Learning Approach and Soft-skills Contribution toward Mathematical Higher Order Thinking Skills of Junior High School Students. American Journal of Educational Research, Vol. 7, No. 12, 925-929.

[21] NCTM. (2000). Principles and standards for school mathematics. Reston, VA: The National Council of Teachers of Mathematics, Inc.

[22] Noordyana. 2016. Improving Students' Mathematical Critical Thinking Ability Through Metacognitive Instruction Approach. Journal of "Mosharafa", Volume 8, Number 2, April 2016, pp: 28-35. ISSN 2086 4280. Journal of Mathematics Education STKIP Garut. https://:journalmtk.stkip-garut.ac.id. E-mail: disty.0101@gmail.com

[23] Pambudi. 2007. Various Alternative Models and Approaches in Mathematics Learning. Journal of Mathematics Education, Volume 1, No.2, July 2007.

[24] Roestiyah. 2001. Teaching and learning strategies. Jakarta: PT. Rineka Cipta.

[25] Rosyidah. 2016. The Influence of Jigsaw Type Cooperative Learning Model on Mathematics Learning Outcomes of Class VIII Students of SMP Negeri 6 Metro. SAP Journal Vol. 1 No. December 2, 2016, pp: 115-124. ISSN: 2527-967X. Email: ummirosyium09@gmail.com

[26] Rusman. 2010. Learning Models to Develop Teacher Professionalism. Jakarta: PT Rajagrafindo Persada.

[27] Sary, Hasratuddin, \& Surya. 2019. Effectiveness of Development LKS Based on International Program for Student Assessment (PISA) with Realistic Learning For Improving Mathematical Communication Skills of Student of MTsN 2 Medan. Budapest International Research and Critics in Linguistics and Education (BirLE) Journal. Volume 2, No 2, May 2019, Page: 388-398 e-ISSN: 2655-1470 (Online), p- ISSN: 2655-2647 (Print). Email: birle.journal@gmail.com

[28] Setyawan, Setiawan, \& Pambudi. 2013. Differences in Students' Mathematics Learning Outcomes Who Are Taught Using the Inter Cooperative Model a STAD Type with Jigsaw Type on the subject of Quadrangle in Class VII SMP Muhammadiyah 1 Tile Academic Year 2011/2012. Kadikma, Vol. 4, No. 1, pp. 129- 140, April 2013.

[29] Skemp. 1971. The psychology of learning mathematics. England: Middlesex.

[30] Sugianto, Armanto \& Harahap. 2014. Differences in the Application of Jigsaw and STAD Cooperative 
Learning Models in View of the Reasoning and Mathematical Communication Ability of High School Students. Journal of Didactic Mathematics Vol. 1, No. 1, April 2014: 96-128. ISSN: 23554185 .

[31] Syahputra, E. 2016. Applied Statistics for Quasi and Pure Experiments. Medan: Unimed Press.

[32] Syarifah. 2017. Application of Jigsaw Type Cooperative Learning in an Effort to Improve Learning Management and Activities of Class V Students of MIS Guppi No.13 Tasik Malaya Curup Utara. Ar-Riyah: Journal of Basic Education. Vol. 1, No. 1, 67-87.

[33] Tran. 2013. Effects of Student Teams Achievement Division (STAD) on Academic Achievement and Attitudes of Grade 9th Secondary School Students towards Mathematics. International Journal of Science, Vol 2 Issue Apr 2013. 